\title{
Pengaruh Dominan Cash Ratio dan Debt to Asset Ratio Terhadap Return on Equity dan Return on Assets pada Perusahaan Astra Otoparts Di Bursa Efek Indonesia
}

\author{
Jhon Nasyaroeka* \\ STIE Prasetiya Mandiri Lampung, Lampung \\ *email: jhonnasyaroeka@gmail.com
}

\begin{tabular}{|c|c|}
\hline A RTICLE INFO & $A B S T R A C T$ \\
\hline Artikel History: & This research is to find out which influence is the most dominant \\
\hline Received: July 21, 2020 & $\begin{array}{l}\text { between cash ratio and debt to assets ratio to return on equity } \\
\text { and return on assets on astra otoparts companies listed on the }\end{array}$ \\
\hline Revised: August 18, 2020 & Indonesia Stock Exchange. This research also provides \\
\hline Published:August 19, 2020 & $\begin{array}{l}\text { information on the dominant influence of cash ratio on return on } \\
\text { equity and Return on Assets and the dominant influence of debt }\end{array}$ \\
\hline $\begin{array}{l}\text { Keywords: } \\
\text { Dominant influence, Cash } \\
\text { ratio, Debt to asset ratio, } \\
\text { Return on equity, Return on }\end{array}$ & $\begin{array}{l}\text { to assets ratio to return on equity and return on assets. The } \\
\text { results obtained from this study are the dominant influence of } \\
\text { cash ratio and debt to assets ratio to return on assets. This } \\
\text { shows the amount of contribution of company assets. }\end{array}$ \\
\hline
\end{tabular}
assets.

\section{N F O A R T I K E L}

Riwayat Artikel:

Diterima : 21 Juli 2020

Direvisi: 18 Agustus 2020

Dipublikasikan : 19 Agustus 2020

\section{Kata kunci:}

Pengaruh dominan, Rasio kas, Rasio utang terhadap aset, Laba atas ekuitas, Laba atas aset

\section{A B S T R A K}

Penelitian ini adalah untuk mengetahui pengaruh mana yang paling dominan antara rasio kas dan rasio hutang terhadap aset terhadap return on equity dan return on asset pada perusahaan astra otoparts yang terdaftar di Bursa Efek Indonesia. Penelitian ini juga memberikan informasi tentang pengaruh dominan rasio kas terhadap pengembalian ekuitas dan Imbal Hasil Aset dan pengaruh dominan rasio utang terhadap aset terhadap pengembalian ekuitas dan laba atas aset. Hasil yang diperoleh dari penelitian ini adalah pengaruh dominan rasio kas dan rasio hutang terhadap aktiva terhadap pengembalian aktiva. Ini menunjukkan besarnya kontribusi aset perusahaan. 


\section{PENDAHULUAN}

Pasar modal merupakan salah satu sarana yang efektif dalam pembentukan modal dan alokasi Dana yang diarahkan untuk meningkatkan partisipasi masyarakat dalam menunjang pembangunan pembiayaan nasional guna mendorong pertumbuhan ekonomi dan peningkatan kesejahteraan masyarakat. Segala aktivitas yang dilakukan perusahaan tidak hanya serta merta tanpa penilaian dan diuji, tetapi perlu adanya pertanggungjawabkan. Untuk pertanggung jawaban tersebut diperlukan suatu laporan keuangan ,dimana laporan keuangan merupakan media komunikasi dan pertanggungjawaban antara perusahaan (manajemen) dan para pemiliknya atau pihak lainnya.Laporan keuangan merupakan sebuah media informasi yang mencatat, merangkum segala aktivitas perusahaan dan digunakan untuk melaporkan keadaan dan posisi perusahaan pada pihak yang berkepentingan, terutama pada pihak kreditur, investor, dan manajemen perusahaan itu sendiri. Pemilik suatu usaha akan mengetahui kondisi keuangan dan kemajuan usahanya. Perusahaan Astra Otoparts adalah perusahaan yang bergerak dibidang otomotif terkemuka Indonesia yang memproduksi dan mendistribusikan suku cadang kendaraan bermotor baik kendaraan roda dua maupun roda empat. Perusahaan tersebut termasuk dalam perusahaan yang telah go public, artinya laporan keuangannya bersifat terbuka, sehingga dapat dilihat dan dibaca oleh masyarakat umum terutama pihak-pihak yang berkepentingan dengan laporan keuangannya. Dan dari laporan keuangan inilah suatu perusahaan akan terlihat juga kinerjanya. Dan setiap perusahaan dalam menjalankan usaha bertujuan untuk memaksimalkan kesejahteraan pemilik atau shareholder, melalui keputusan atau kebijakan investasi, keputusaan pendanaan, dan keputusan deviden yang tercermin dalam harga saham dipasar modal, demikian juga dilihat dari sudut pandang manajemen keuangan. Analisis rasio memungkinkan manajer keuangan dan pihak yang berkepentingan untuk mengevaluasi kondisi keuangan dan pihak yang berkepentingan untuk mengevaluasi kondisi keuangan akan menunjukkan kondisi sehat tidaknya perusahaan. Analisis rasio juga menghubungkan unsur-unsur rencana dan perhitungan laba rugi sehingga dapat menilai efektivitas dan efisiensi suatu perusahaan.Untuk kekayaan perusahaan dapat diketahui juga dengan diukur melalui ROA atau return on assets yang dikenal juga dengan istilah ROI (Return On Insvetment) sedangkan untuk laba perusahaan itu sendiri diukur melalui ROE (Return On Equity) . ROA atau ROI dalam analisa keuangan mempunyai arti sangat penting sebagai salah satu tehnik analisa keuangan yang bersifat menyeluruh (komprehensif). Karena analisa ROA ini sudah merupakan tehnik analisa yang lazim atau biasa digunakan oleh pimpinan perusahaan untuk mengukur efektivitas dari keseluruhan operasi perusahaan. ROA itu sendiri adalah salah satu bentuk dari rasio profitabilitas yang dimaksudkan untuk dapat mengukur kemampuan perusahaan dengan keseluruhan dana yang ditanamkan dalam aktiva yang digunakan untuk operasinya perusahaan 
untuk menghasilkan keuntungan atau laba. Dengan demikian rasio ini menghubungkan keuntungan yang diperoleh dari operasi perusahaan (net operating income) dengan jumlah investasi atau aktiva yang digunakan untuk menghasilkan keuntungan operasi tersebut (net operating assets). Sedangkan untuk ROE digunakan untuk mengukur efektivitas perusahaan di dalam menghasilkan keuntungan dengan memanfaatkan ekuitas yang dimilikinya. Ukuran untuk mengetahui sampai sejauh mana perusahaan mampu memberikan kemakmuran kepada para pemilik atau shareholder dapat dianalisis melalui tingkat return on equity (ROE). ROE dapat dikatakan sebagai kemampuan perusahaan dalam menyediakan laba bagi pemegang saham atas modal yang telah ditanam oleh investor. Semakin tinggi ROE, efisiensi pada penggunaan modal sendiri oleh perusahaan akan semakin lebih baik dan kemampuan perusahaan untuk memaksimalkan kesejahteraan pemilik juga akan meningkat.

Keuntungan atau laba yang besar pada suatu perusahaan dapat dipengaruhi oleh beberapa faktor,salah satunya yang digunakan dalam penelitian ini adalah Cash Rasio (CR) dan Debt to Assets Rasio (DAR). Cash rasio merupakan alat yang digunakan untuk mengukur seberapa besar uang kas yang tersedia untuk membayar utang. Rasio yang tinggi atau rendah akan mempengaruhi laba atau keuntungan yang akan diperoleh perusahaan.Sedangkan untuk Debt to Assets Rasio yang merupakan rasio utang yang digunakan untuk mengukur perbandingan antara total utang dengan total aktiva akan berpengaruh terhadap pengelolaan aktiva.Dimana apabila rasionya tinggi maka akan sulit perusahaan memperoleh tambahan pinjaman dan dikhawatirkan perusahaan tidak mampu menutupi utangnya dengan aktiva yang dimiliknya,sehingga apabila rasio rendah semakin kecil perusahaan dibiayai dengan utang (Kasmir, 2014:156). Dalam menjalankan kegiatan operasionalnya, setiap perusahaan menginginkan keuntungan (laba). Pengertian laba menurut Harahap (2010:263) yang penting dalam laporan keuangan antara lain :

a. Laba merupakan dasar dalam perhitungan pajak, pedoman dalam menentukan kebijakan investasi dan pengambilan keputusan, dasar dalam peramalan laba maupun kejadian ekonomi perusahaan lainnya dimasa yang akan datang, dasar dalam perhitungan penilaian prestasi atau kinerja".

b. Pertumbuhan laba menjadi informasi yang sangat penting bagi banyak orang, yang antaralain adalah penguasa, analis keuangan, pemegang saham, ekonomi dan sebagainya. Tujuan utama pelaporan laba adalah memberikan inforrmasi yang berguna bagi mereka yang paling berkepentingan dalam laporan keuangan.

c. Pertumbuhan laba dari tahun ketahun juga dijadikan sebagai dasar efisiensi manajemen dan membantu meramalkan arah masda depan perusahaan atau pembagian dividen masa depan. 
Laporan keuangan pada dasarnya merupakan hasil dari proses akuntansi yang terdiri dari salah satunya adalah neraca, laporan laba rugi, laporan perubahan modal, laporan arus kas yang bisa digunakan sebagai alat untuk mengetahui aktivitas perusahaan dengan pihak-pihak yang berkepentingan dengan aktivitas tersebut. Rasio keuangan merupakan rasio yang terdiri dari rasio likuiditas, rasio solvabilitas, rasio aktivitas dan rasio profitabilitas. Sedangkan, rasio likuiditas menurut Riyanto (2008: 25) adalah masalah yang berhubungan dengan masalah kemampuan suatu perusahaan untuk memenuhi kewajiban financialnya yang segera harus dipenuhi.Adapun Jenis-jenis rasio likuiditas yang dapat digunakan perusahaan untuk mengukur kemampuan, yaitu: Rasio Lancar (Current Ratio), Rasio Sangat Lancar (Quick Ratio atau Acid Test Ratio), Rasio Kas (Cash Ratio), Inventory to Net Working Capital.

Dalam menjalankan kegiatan operasinya perusahaan memiliki berbagai kebutuhan, terutama yang berkaitan dengan dana agar perusahaan dapat berjalan sebagaimana mestinya (Kasmir, 2014 :150-151). Adapun jenis-jenis rasio solvabilitas yang ada dalam rasio solvabilitas antara lain (a) Debt to Asset Rastio (Debt Ratio), (b) Long Term Debt to Equity Ratio (LTDtER), (c) Times Interest Earned, (d)Fixed Charge Coverage.

Rasio aktivitas merupakan rasio yang digunakan untuk mengukur efektivitas perusahaan dalam mengatakan aktiva yang dimilikinyaBerikut ini beberapa jenis-jenis rasio aktivitas dari beberapa ahli keuangan, yaitu: (a) Peputaran Piutang (Receivable Turnover), (b) Peputaran Sediaan (Inventory Turnover), (c) Peputaran Modal Kerja (Working Capital Turnover), (d) Fixed Asset Turover, (d) Total assets turnover.

Rasio profitabilitas atau bisa disebut juga rasio rentabilitas merupakan rasio untuk memulai kemampuan perusahaan dalam mencari keuntungan,Fahmi (2011 : 134). Dalam praktiknya, jenisjenis rasio profitailitas yang dapat digunakan adalah:

a) Profit margin (profit margin on sales)

Ada dua rumus untuk mencari rasio profit margin, yaitu sebagai berikut:

(1) Untuk margin laba kotor dengan rumus:

Penjualan Bersih + Harga Pokok Penjualan (Laba Kotor)

Penjualan

(2) Untuk margin laba bersih dengan rumus:

Laba Setelah Bunga dan Pajak (Laba Bersih)

Penjualan

b) Return On Investment (ROI)

Besarnya suatu ROI dipengaruhi oleh dua faktor, diantaranya:

(1)Turnover dari operating assets (tingkat peputaran aktiva yang digunakan untuk operasi), 
(2) Profit margin, yaitu besarnya keuntungan operasi yang dinyatakan dalam persentase dan jumlah penjualan bersih.

c) Hasil Pengambilan Ekuitas (Return on Equity/ROE)

d) Laba Per Lembar Saham (Earning per Share of common Stock)

e) Return On Equity (ROE)

\section{Pengaruh Dominan Cash Rasio dan Debt to Assets Rasio Terhadap Return On Equity dan Return on Assets}

Cash Rasio (CR) merupakan rasio untuk mengukur kemampuan perusahaan seberapa besar uang kas yang tersedia untuk membayar utang .Apabila tingkat CR tinggi maka perusahaan dikatakan mampu untuk membayar kewajibannya. Jika CR tinggi juga menunjukkan bahwa terdapat aktiva lancar yang lebih yang tidak digunakan secara efektif yang akan menyebabkan berkurangnya keuntungan atau laba yang akan mengakibatkan semakin kecinya ROE.Sedangkan pada ROA melihat sejauh mana investasi yang telah ditanamkan mampu memberikan pengembalian keuntungan sesuai dengan yang diharapkan perusahaan. Debt to Assets Rasio (DAR) merupakan rasio utang untuk mengukur perbandingn antara total utang dengan total aktiva.Semakin tinggi rasio DAR maka pendanaan dengan utang semakin banyak yang berarti semakin sulit perusahaan untuk memperoleh pinjaman karena dikhawatirkan perusahaan tidak mampu menutupi utang utangnya dengan aktiva yang dimilikinya.Jika rasio ini rendah maka semakin kecil perusahaan dibiayai dengan utang (Kasmir,2014:156).Sehingga hal ini akan berpengaruh terhadap pembiayaan asset yang akan juga mempengaruhi laba atau keuntungan. Sehingga, Penelitian ini akan memberikan kedominanan antara Cash Rasio dan Debt to Assets Rasio terhadap Return On Equity Pada perusahaan Astra Otoparts, maupun antara Cash Rasio dan Debt to Assets Rasio terhadap Return On Assets Pada perusahaan Astra Otoparts. 


\section{METODE PENELITIAN}

\section{Populasi dan Sampel}

Populasi dalam penelitian ini adalah perusahaan astra otoparts yang terdaftar di BEI dengan data laporan keuangan pada periode tahun 2018. Sampel yang digunakan dalam penelitian ini adalah perusahaan-perusahaan yang bergerak dibidang suku cadang. Dan metode yang digunakan dalam penelitian ini adalah metode pruposive sampling. yaitu teknik pengambilan sampel sumber data, dengan pertimbangan tertentu, Sugiyono (2011 : 126). Adapun pertimbangan-pertimbangan yang digunakan adalah sebagai berikut:

1) Perusahaan astra otopatrs yang terdaftar di Bursa Efek Indonesia (BEI) pada tahun 2018.

2) Laporan keuangan yang menyajikan kas dan setara kas, utang lancar, total utang, total aset, penjualan, serta laba bersih yang lampirkan pada tahun 2018.

\section{Jenis data dan Sumber Data}

Untuk melakukan analisis dan pembahasan terhadap data yang diperoleh menggunakan metode analisis sebagai berikut :

Analisis kualitatif adalah analisis data yang berbentuk uraian kata-kata atau keterangan yang didapat dari objek penelitian.

Analisis kuantitatif adalah analisis data mengunakan data kuantitatif (angka-angka) terhadap objek penilaian .

\section{Teknik Pengumpulan Data}

Metode yang dipergunakan dalam penelitian ini metode dokumentasi,yaitu penelitian yang menggunakan metode pengumpulan data dengan melihat laporan keuangan di tahun 2018 . Adapun data laporan keuangan diambil dari situs resmi BEI dengan alamat yaitu www.idx.co.id

\section{Definisi Operasional Variabel}

a. Variabel Dependen

Variabel dependen yang digunakan dalam penelitian ini adalah ROE dan ROA sebagai berikut:

1). Rasio return on Equity (ROE)

Laba Setelah Bunga dan Pajak (Laba Bersih) 
2).Rasio Return on Assets (ROA)

Total Asset Turnover x Profit Margin

b. Variabel Independen

Variabel independen yang digunakan dalam penelitian ini adalah cash ratio dan debt to asset rasio. Dengan perhitungan sebagai berikut:

1) Cash Ratio

Berikut adalah rumus yang digunakan untuk menghitung rasio kas:

Cash And Cash Equivalent

Current Liabilities

2) Debt to Asset Ratio

Rumusnya:

$\frac{\text { Total Debt }}{\text { Total Assets }}$

\section{Alat Analisis}

\section{Uji Koefisien Determinasi $\mathbf{R}^{2}$}

Koefesien determinasi pada regresi linear sering diartikan seberapa besar kemampuan semua variabel bebas dalam menjelaskan varians dan variabel terikatnya. Secara sederhana koefisien determinasi dengan melihat $R$ square $\left(R^{2}\right)$.

\section{Persamaan Regresi berganda}

Ada 2 persamaan Regresi berganda karena ada 2 variabel independen dan dua variabel dependent.

Adapun persamaannya adalah

$$
\begin{aligned}
& Y 1=a+b X_{1}+b X_{2} \\
& Y 2=a+b X_{1}+b X_{2}
\end{aligned}
$$

Keterangan:

$Y=$ variable Dependent $(R O E)$ dan (ROA)

$a=$ konstanta

$X_{1}=$ Cash rasio $(C R)$

$X_{2}=$ Debt to Assets Rasio (DAR) 
Metode analisis data yang digunakan dalam penelitian ini adalah metode analisis statistic, dengan program SPSS. Koefisien determinansi $\mathrm{R}^{2}$ untuk mengetahui pengaruh dominan diantara cash rasio dan debt to assets rasio terhadap return on equity serta pengaruh dominan cash ratio dan debt to assets ratio terhadap return on assets.

\section{HASIL DAN PEMBAHASAN}

\section{Hasil Penelitian}

\section{Uji Hipotesis}

Hasil uji regresi linier berganda pada variabel independent Cash Rasio dan Debt to asset rasio terhadap variabel dependent Return on Equity, yang disajikan pada tabel 2 berikut ini.

Tabel 1. Hasil Uji Regresi Linier Berganda

\begin{tabular}{|c|c|c|c|c|c|}
\hline \multirow[t]{2}{*}{ Model } & \multicolumn{2}{|c|}{$\begin{array}{l}\text { Unstandardized } \\
\text { Coefficients }\end{array}$} & $\begin{array}{l}\text { standardized } \\
\text { Coefficients }\end{array}$ & $\mathrm{t}$ & Sig \\
\hline & B & Std.Error & Beta & & \\
\hline (constant) & -108.645 & 321.501 & & $\begin{array}{l}-1.932 \\
.211\end{array}$ & \\
\hline $\mathrm{CR}$ & .112 & .053 & .632 & $\begin{array}{l}2.212 \\
.064\end{array}$ & \\
\hline DAR & 3.134 & 2.546 & .139 & $\begin{array}{l}.826 \\
.382\end{array}$ & \\
\hline
\end{tabular}

Dependent Variable: ROE

Sumber: data sekunder yang diolah 2020

$\mathrm{ROE}=\mathrm{a}+\mathrm{b} \mathrm{X}_{1}+\mathrm{b} \mathrm{X}_{2}+\mathrm{bX}$

$\mathrm{ROE}=-108.645+0.112 \mathrm{CR}+3.134 \mathrm{DAR}$

Interpretasi yang didapat dinyatakan dari persamaan regresi diatas sebagai berikut:

1. nilai konstanta sebesar -108.645 yang artinya jika nilai CR dan DAR memiliki nilai sama dengan 0 maka nilai ROE sebesar -108.645.

2. nilai CR sebesar 0,112 dengan koefisien positif yang artinya setiap CR meningkat satu satuan ,maka ROE akan mengalami peningkatan sebesar 0,112 satuan dengan asumsi bahwa variable bebas/independen yang lainnya dianggap kontans.

3. nilai DAR sebesar 3.134 dengan koefisien positif yang artinya setiap DAR meningkat satu satuan, maka ROE akan mengalami peningkatan sebesar 3.134 satuan dengan asumsi bahwa variable bebas/independen yang lainnya dianggap kontan. 
Untuk hasil uji regresi linier berganda pada variabel independent Cash Rasio dan Debt to asset rasio terhadap variabel dependent Return on Assets, yang disajikan pada tabel 3 berikut ini.

Tabel 2. Hasil Uji Regresi Linier Berganda

\begin{tabular}{|c|c|c|c|c|c|}
\hline \multirow[t]{2}{*}{ Model } & \multicolumn{2}{|c|}{$\begin{array}{l}\text { Unstandardized } \\
\text { Coefficients }\end{array}$} & $\begin{array}{l}\text { standardized } \\
\text { Coefficients }\end{array}$ & $\mathrm{t}$ & Sig \\
\hline & B & Std.Error & Beta & & \\
\hline (constant) & -106.852 & 156.521 & & $\begin{array}{l}-1.399 \\
.201\end{array}$ & \\
\hline $\mathrm{CR}$ & .042 & .023 & .701 & $\begin{array}{l}2.346 \\
.031\end{array}$ & \\
\hline DAR & -.126 & .754 & -.059 & $\begin{array}{l}-.210 \\
.403\end{array}$ & \\
\hline
\end{tabular}

\section{Dependent Variable: ROA}

Sumber: data sekunder yang diolah 2020

$$
\begin{aligned}
& \mathrm{ROA}=\mathrm{a}+\mathrm{b} \mathrm{X}_{1}+\mathrm{b} \mathrm{X}_{2}+\mathrm{bX}_{3} \\
& \mathrm{ROA}=-106.852+0.042 \mathrm{CR}-0.126 \mathrm{DAR}
\end{aligned}
$$

Interpretasi yang didapat dinyatakan dari persamaan regresi diatas sebagai berikut:

1. nilai konstanta sebesar -106.852 yang artinya jika nilai CR dan DAR memiliki nilai sama dengan 0 maka nilai ROA sebesar -106.852 .

2. nilai CR sebesar 0,042 dengan koefisien positif yang artinya setiap CR meningkat satu satuan maka ROA akan mengalami peningkatan sebesar 0,042 satuan dengan asumsi bahwa variable bebas/independen yang lainnya dianggap kontans.

3. nilai DAR sebesar -0,126 dengan koefisien negatif yang artinya setiap DAR menurun satu satuan maka ROA akan mengalami penurunan sebesar -0,126 satuan dengan asumsi bahwa variable bebas/independen yang lainnya dianggap kontan.

\section{Uji Koefisien Determinansi $\mathbf{R}^{2}$}

Uji determinan $\mathrm{R}^{2}$ digunakan untuk mengetahui seberapa besar kemampuan semua variabel bebas dalam menjelaskan varians variable terikatnya.

Berdasarkan hasil kuantitatif yang didapat dari pengolahan data melalui program SPSS versi 20 maka didapat output sebagai berikut: 
Tabel 3.Hasil uji Koefisien Determinasi $\mathrm{R}^{2}$ : CR,DAR terhadap ROE

\begin{tabular}{lrrrrr}
\hline Model & $\mathrm{R}$ & R Square & $\begin{array}{l}\text { Adjusted } \\
\text { Square }\end{array}$ & $\begin{array}{l}\mathrm{R} \\
\text { Std.Error of the } \\
\text { Estimate }\end{array}$ \\
\hline 1 & $.753^{\mathrm{a}}$ & .346 & & .128 & 659.011
\end{tabular}

Predictors: (Constant),CR,DAR

Sumber : data sekunder diolah ,2020

Hasil perhitungan uji koefisien determinasi $\mathrm{R}^{2}$ model pertama diperoleh hasil RSquare/R determinansi sebesar 0,346 yang akan diubah menjadi prosentase yaitu 34,6\% yang artinya Cash rasio (CR) dan Debt to asset rasio (DAR) memberikan pengaruh sebesar $34,6 \%$ terhadap ROE sedangkan sisanya dipengaruhi oleh factor lain yang tidak diteliti.Sedangkan pada Adjusted R square sebesar 0,128 yang artinya variabel independent (CR dan DAR) sangat memberikan pengaruh yang besar terhadap variabel dependent (ROE), dengan std.Error sebesar 659.011.

Tabel 4. Hasil uji Koefisien Determinasi $\mathrm{R}^{2}$ : CR,DAR terhadap ROA

\begin{tabular}{lrrrrr}
\hline Model & $\mathrm{R}$ & $\mathrm{R}$ Square & $\begin{array}{l}\text { Adjusted } \\
\text { Square }\end{array}$ & $\begin{array}{l}\mathrm{R} \\
\text { Std.Error of the } \\
\text { Estimate }\end{array}$ \\
\hline 1 & $.815^{\mathrm{a}}$ & .624 & .332 & 241.027
\end{tabular}

Predictors: (Constant),CR,DAR

Sumber : data sekunder diolah ,2020

Hasil perhitungan uji koefisien determinasi $\mathrm{R}^{2}$ model pertama diperoleh hasil RSquare/R determinansi sebesar 0,624 yang akan diubah menjadi prosentase yaitu 62,4\% yang artinya Cash rasio (CR) dan Debt to asset rasio (DAR) memberikan pengaruh sebesar $62,4 \%$ terhadap ROA sedangkan sisanya dipengaruhi oleh factor lain yang tidak diteliti.Sedangkan pada Adjusted R square sebesar 0,332 yang artinya variabel independent (CR dan DAR) sangat memberikan pengaruh yang besar terhadap variabel dependent (ROA).

\section{Pembahasan}

Untuk pengaruh dominan pada cash rasio dan debt to assets rasio terhadap Return on Equity mempunyai nilai RSquare/R determinansi sebesar 0,346 yang akan diubah menjadi prosentase yaitu sebesar 34,6\% yang artinya Cash rasio (CR) dan Debt to asset rasio (DAR) memberikan pengaruh sebesar 34.6\% terhadap ROE sedangkan sisanya dipengaruhi oleh factor lain yang tidak diteliti oleh penulis.Sedangkan pengaruh dominan Cash rasio dan Debt to Assets rasio terhadap Return on 
Equity dan Return on Assets pada perusahaan astra otoparts yang paling berpengaruh dominan adalah pada cash rasio dan debt to assets rasio terhadap Return on Assets.Hal ini karena Cash rasio dan Debt to assets rasio terhadap return on assets mempunyai nilai RSquare/R determinansi sebesar 0,624 yang akan diubah menjadi prosentase yaitu 62,4\% yang artinya Cash rasio (CR) dan Debt to asset rasio (DAR) memberikan pengaruh sebesar 62,4\% terhadap ROA sedangkan sisanya dipengaruhi oleh factor yang tidak diteliti oleh penulis.

Penelitian ini juga konsisten dengan teori yang dikemukakan oleh Fahmi (2011) dan milyati rina (2016), bahwa debt to assets rasio (DAR) merupakan keseluruhan assets yang dimiliki perusahaan dibiayai oleh kewajiban atau hutang.Sedangkan pada Cash Rasio (CR) merupakan rasio yang mengukur kemampuan perusahaan dalam membayar kewajiban jangka pendek. Sehingga jika ROA semakin baik maka perusahaan akan mampu untuk memaksimalkan kesejahteraan pemilikdan juga investor.

\section{KESIMPULAN DAN SARAN}

Variabel Cash ratio (CR) dan Debt to Assets rasio (DAR) mempunyai $\mathrm{R}$ Square/R Determinasi sebesar 0,346 terhadap Return on equity (ROE) sehingga dapat diketahui bahwa variabel CR dan DAR mempunyai pengaruh sebesar 34,6\% terhadap ROE. Sedangkan, variabel Cash ratio (CR) dan debt to asset ratio (DAR) mempunyai R Square/R Determinasi sebesar 0,624 terhadap Return on Assets (ROA) sehingga dapat diketahui bahwa variabel CR dan DAR mempunyai pengaruh sebesar $62,4 \%$ terhadap ROA. Hasil penelitian menunjukkan cash ratio dan debt to assets ratio memiliki pengaruh dominan terhadap return on Assets.

\section{DAFTAR PUSTAKA}

Fahmi, Irham.2011. Analisis Laporan Keuanga,n Edisi Pertama. Alfabeta. Bandung.

Hasanuh, Nanu. 2011. Akuntansi Dasar : Teori dan Praktik, Edisi Pertama. Mitra Wacana Media. Jakarta.

Hery. 2015. Analisis Laporan Keuangan, PT Buku Seru. Cet 1. Yogyakarta.

Hery. 2015. Pengantar Akuntansi Compehensive Edition "Lengkap dengan Kumpulan Soal dan Solusinya”, PT Grasindo. Jakarta.

Kasmir. 2014. Analisis Laporan Keuangan, Edisi Pertama (Revisi). PT RajaGrafindo Persada. Jakarta.

Kuncoro, Mudrajad. 2011. Metode Kuantitatif, Edisi Empat. Unit Penerbit dan Percetakan Sekolah Tinggi Ilmu Manajemen. Yogyakarta

Munawir. 2010. Analisa Laporan Keuangan, Edisi Keempat. Liberty. Yogyakarta. 
Nahor, I. Banjar. 2015. Skripsi Akuntans "Analisis Debt To Asset Ratio, Current Ratio, Cash Turnover Terhadap Return On Equity”, Bandar Lampung : STIE Gentiaras.

Setiyawan,P Pardiman- nominal: Barometer Riset Akuntansi, 2014, Pengaruh Current ratio,Inventory turnover,Time Interest earnd dan Return On Equity terhadap harga saham pada perusahaan manufaktur sector barang konsumsi yang terdaftar di BEI periode 2009 2012 -journal.uny.ac.id

Syamsuddin,Lukman.2011.Manajemen Keuangan Perusahaan, PT Raja Grafindo Persada, Jakarta

Pura, Rahman. 2013. Pengantar Akuntansi 1 : Pendekatan Siklus Akuntansi, Edisi Pertama. Erlangga. Jakarta.

Yuniastuti,milyati rina.2016,Pengaruh Dominan Current ratios,Debt to asset ratio,total assrts turnover terhadap return on equity pada perusahaan Retail Trade di Bursa Efek Indonesia,Jurnal ilmiah Gema Ekonomi Vol.6 no.2 Agustus 2016.Lampung.

Yuniastuti,milyati rina.2016,Pengaruh Dominan Cash ratio dan Debt to asset ratio terhadap return on equity dan return on assets pada perusahaan Transportasi di Bursa Efek Indonesia,Jurnal Manajemen Magister, Vol 02 no.01 Januari 2016.Lampung. 